\title{
SISTEM INFORMASI PENILAIAN KINERJA (Studi Kasus di SMK Ibrahimy Sukorejo-Situbondo)
}

\author{
M. Ainul Yaqin ${ }^{1}$, Endah Layli Octavia ${ }^{2}$ \\ Jurusan Teknik Informatika \\ Universitas Islam Negeri (UIN) Maulana Malik Ibrahim Malang \\ a_yaqinov@yahoo.com,octavia.elock@gmail.com
}

\begin{abstract}
ABSTRAK
Berdasarkan UU No 20 Tahun 2003 tentang Sistem Pendidikan Nasional, menyatakan bahwa sistem pendidikan nasional harus mampu menjamin pemerataan kesempatan pendidikan, peningkatan mutu serta relevansi dan efisiensi manajemen pendidikan untuk menghadapi tantangan sesuai dengan tuntutan perubahan kehidupan lokal, nasional, dan global sehingga perlu dilakukan pembaharuan pendidikan secara terencana, terarah, dan berkesinambungan. Berkaitan dengan hal tersebut, kepala sekolah SMK merasa sulit untuk memonitoring kegiatan tersebut secara detail dengan cara manual Untuk itu, perlu adanya suatu aplikasi yang dapat memudahkan kepala sekolah SMK dalam memonitoring penilaian kinerja guru, karyawan serta kegiatan pembelajaran yang terjadi. Sistem Penilaian Kinerja ini mampu menghasilkan informasi berupa tabel dan grafik serta detail dari nilai untuk masing-masing indikator per tahun untuk tiap-tiap jurusan keahliannya.
\end{abstract}

Kata Kunci: Sistem Penilaian Kinerja, SMK

\section{Pendahuluan}

A. Latar Belakang

Peraturan Pemerintah Nomor 19 Tahun 2005 tentang Standar Nasional Pendidikan, Pasal 86 ayat (1) menyatakan bahwa sekolah perlu dilakukan akreditasi pada setiap jenjang dan satuan pendidikan untuk menentukan kelayakan program dan/atau satuan pendidikan. Kegiatan pembelajaran tentunya menghasilkan banyak sekali data-data yang harus disimpan dengan baik dan tidak boleh hilang. Data-data laporan kegiatan pembelajaran seperti aktivtas akademik dan kepegawaian yang berlangsung pada sekolah tersebut. Data tersebut merupakan data penting yang dapat menjadi bukti bahwa sebuah sekolah telah melaksanakan kegiatan belajar mengajar.

Pengolahan data penilaian kinerja di instansi masih menggunakan cara manual, sehingga pimpinan

M. Ainul Yaqin adalah dosen Jurusan Teknik Informatika, Fakultas Sains dan Teknologi,Universitas Islam Negeri Maulana Malik Ibrahim Malang email: a_yaqinov@yahoo.com, Endah Layli Octavia adalah mahasiswa Jurusan Teknik Informatika, Fakultas Sains dan Teknologi,Universitas Islam Negeri Maulana Malik Ibrahim Malang, email : octavia.elock@gmail.com dalam instansi ini masih mengalami kesulitan dalam memantau kegiatan penilaian kinerja guru, karyawan

maupun kegiatan pembelajaran. Selain itu, pencatatan

data yang dilakukan pada banyak file pada tempat yang berbeda, hal ini membutuhkan waktu yang lama pada saat melakukan pengolahan data untuk menyusun laporan, sehingga cara manual kurang efektif untuk proses pengolahan data. Karena hal tersebut, sehingga dibutuhkan sebuah bantuan teknologi informasi berupa sistem informasi untuk mengolah data-data serta dapat mementau dan melaporkan penilaian kinerja guru, karyawan maupun kegiatan pembelajaran yang terjadi pada sekolah tersebut.

\section{B. RUANG LingKup PENELITIAN}

Berdasarkan hasil observasi yang dilakukan, maka dapat disimpulkan adanya permasalahan "Bagaimanakah cara memantau dan mengolah data-data yang ada pada sekolah menjadi pelaporan penilaian kinerja". Sistem informasi ini melaporkan hasil kegiatan yang terjadi pada sekolah baik guru, karyawan maupun kegiatan 
akademik. Berikut adalah ruang lingkup penelitian dari sistem penilaian kinerja:

1. Penyusunan laporan berdasarkan suatu kriteria untuk menunjang kebutuhan informasi secara khusus, antara lain:

a. Laporan penilaian kinerja per kepala program keahlian

b. Laporan penilaian kinerja untuk kepala sekolah

c. Laporan penilaian kinerja per tahun

2. Laporan disajikan dengan tampilan tabel disertai grafik dengan tujuan mempermudah dalam pembacaan data.

\section{ManfaAt Penelitian}

Manfaat dari Sistem Penilaian Kinerja ini diantaranya:
a. Mengurangi biaya cetak dokumen,
b. Mempercepat proses pembuatan laporan kepada kepala sekolah,
c. Meningkatkan keakuratan data penilaian kinerja guru, karyawan serta kegiatan pembelajaran,
d. Mengurangi resiko kehilangan dan kesalahan data,
e. Meningkatkan kualitas laporan penilaian kinerja.

\section{LANDASAN TEORI}

\section{A. Penilaian KinerJa}

Sistem penilaian kinerja adalah sistem yang dibuat untuk menilai dan memonitor kinerja semua pegawai, staf dan proses kegiatan organisasi yang hanya digunakan oleh para eksekutif (pimpinan) dalam sebuah organisasi perusahaan. Dimana dalam sistem tersebut hanya menampilkan grafik dan laporan hasil penilaian kinerja dari seluruh proses kegiatan yang telah dilakukan dalam kurun waktu tertentu.

Penilaian menyediakan informasi yang dapat melayani sasaran organisasi dan mengikuti peraturan, maka sistem penilaian/evaluasi kinerja harus memberikan data yang akurat dan reliabel. Menurut Ivancevich (1992) kemampuan menghasilkan data yang akurat dan reliabel akan meningkat jika mengikuti suatu proses sistematis yang terdiri dari enam langkah, yaitu:

1. mengadakan standar kinerja untuk setiap posisi dan kriteria evaluasinya,

2. mengadakan kebijaksanaan evaluasi kinerja berkaitan dengan kapan penilaian dilakukan, seberapa sering dan siapa yang harus menilai,

3. memiliki penilai yang mengumpulkan data kinerja karyawan,
4. memiliki penilai yang mengevaluasi kinerja karyawan,

5. mendiskusikan evaluasi tersebut dengan karyawan,

6. membuat keputusan dan menyimpan hasil evaluasi tersebut.

\section{B. Sekolah Menengah Kejuruan (SMK)}

Penyelenggaraan sekolah menengah kejuruan didasarkan atas ketentuan yang ada pada UndangUndang Republik Indonesia No. 2 Tahun 1989 tentang sistem pendidikan Nasional Bab IV pasal 11 ayat (1) dan (3) yang berbunyi sebagai berikut: "Jenis pendidikan umum, pendidikan kejuruan, pendidikan luar biasa, pendidikan kedinasan, pendidikan keagamaan, pendidikan akademik, dan pendidikan professional". Sekolah menengah kejuruan berdasarkan tingkatan pendidikan setara dengan sekolah menengah atas, akan tetapi keduanya mempunyai tujuan yang berbeda.

Pengertian mengenai sekolah menengah kejuruan terdapat pada Peraturan Pemerintah No. 74 tahun 2008 pasal 1 ayat 21 yang menyatakan bahwa "Sekolah Menengah Kejuruan yang selanjutnya disingkat SMK adalah salah satu bentuk satuan pendidikan formal yang menyelenggarakan pendidikan kejuruan pada jenjang Pendidikan Menengah sebagai lanjutan dari SMP, MTs, atau bentuk lain yang sederajat atau lanjutan dari hasil belajar yang diakui sama atau setara SMP atau MTs". Sekolah menengah kejuruan melakukan proses belajar mengajar baik teori maupun praktik yang berlangsung di sekolah maupun di industri diharapkan dapat menghasilkan lulusan yang berkualitas. Sekolah menengah kejuruan mengutamakan pada penyiapan siswa untuk berlomba memasuki lapangan kerja.

\section{PERANCANGAN}

Perancangan sistem informasi ini dibagi menjadi beberapa bagian yaitu:
a. Perancangan Sitemap
b. Perancangan Context Diagram
c. Perancangan Entity Relational Diagram (ERD)

\section{Perancangan Sitemap}

Sitemap dibuat berdasarkan kebutuhan fungsional dari sistem yang ada. Sistem ini terdiri dari empat level, yaitu administrator, tata usaha, kepala program keahlian dan kepala sekolah. Sitemap dari Sistem Penilaian Kinerja dapat dilihat pada Gambar 1. 


\section{Perancangan Data Flow Diagram}

Context Diagram penelitian ini merupakan gambaran secara global untuk mengidentifikasi komponen-komponen sistem yang diperlukan secara terperinci. Context
Diagram Sistem Penilaian Kinerja yang dibangun

dapat dilihat
Gambar

2. 


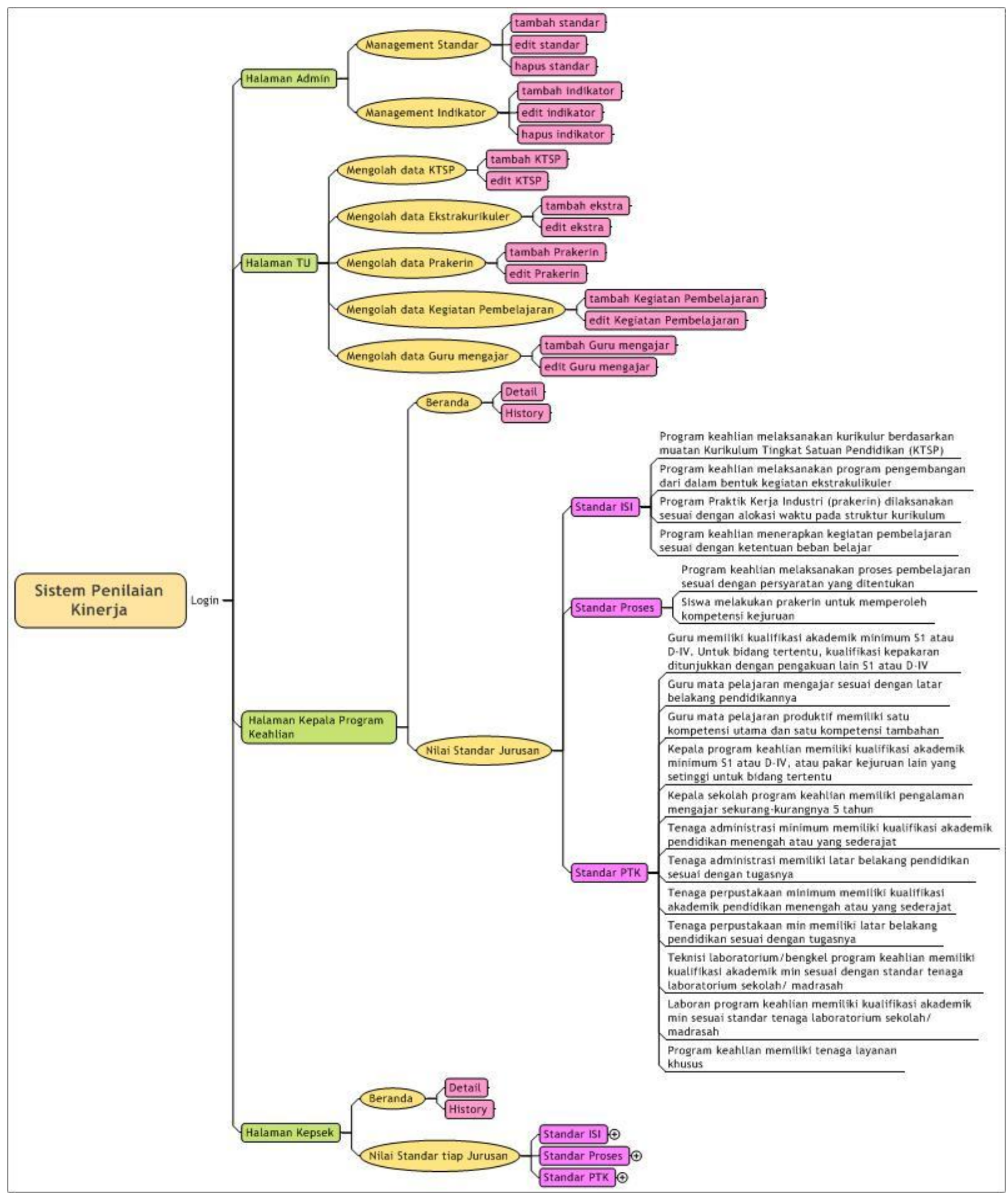

Gambar 1. Sitemap Sistem 


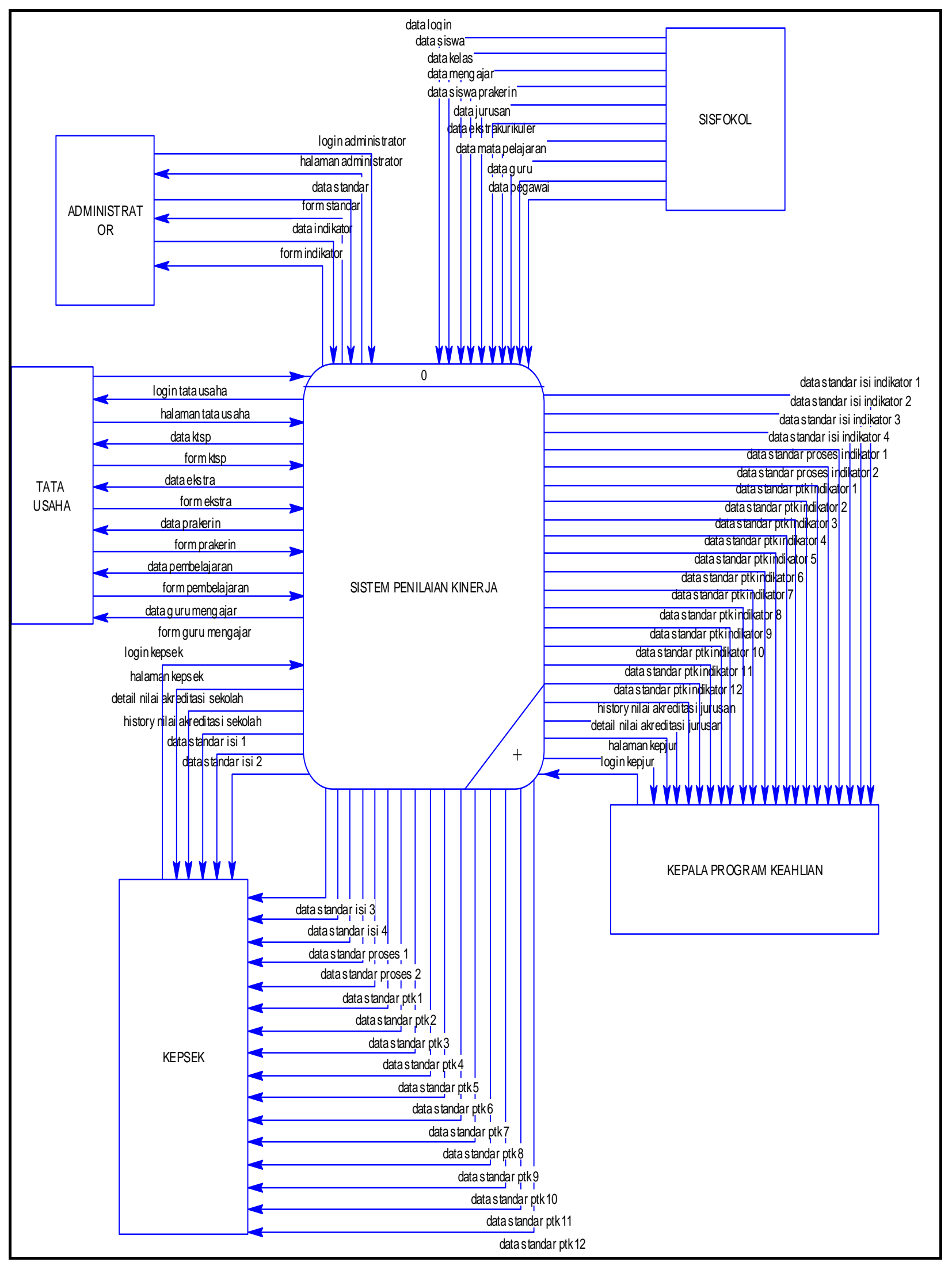


Gambar 2. Context Diagram

Perancangan Entity Relational Diagram (ERD)

Dalam pembuatan sistem ini dibutuhkan desain database untuk menyimpan data yang akan digunakan dalam sistem penilaian kinerja. Desain database menjelaskan tabel-tabel dan field-field yang digunakan guna membantu kinerja sistem secara optimal, sedangkan untuk relasi tabelnya sudah digambarkan pada Entity Relationship Diagram (ERD).

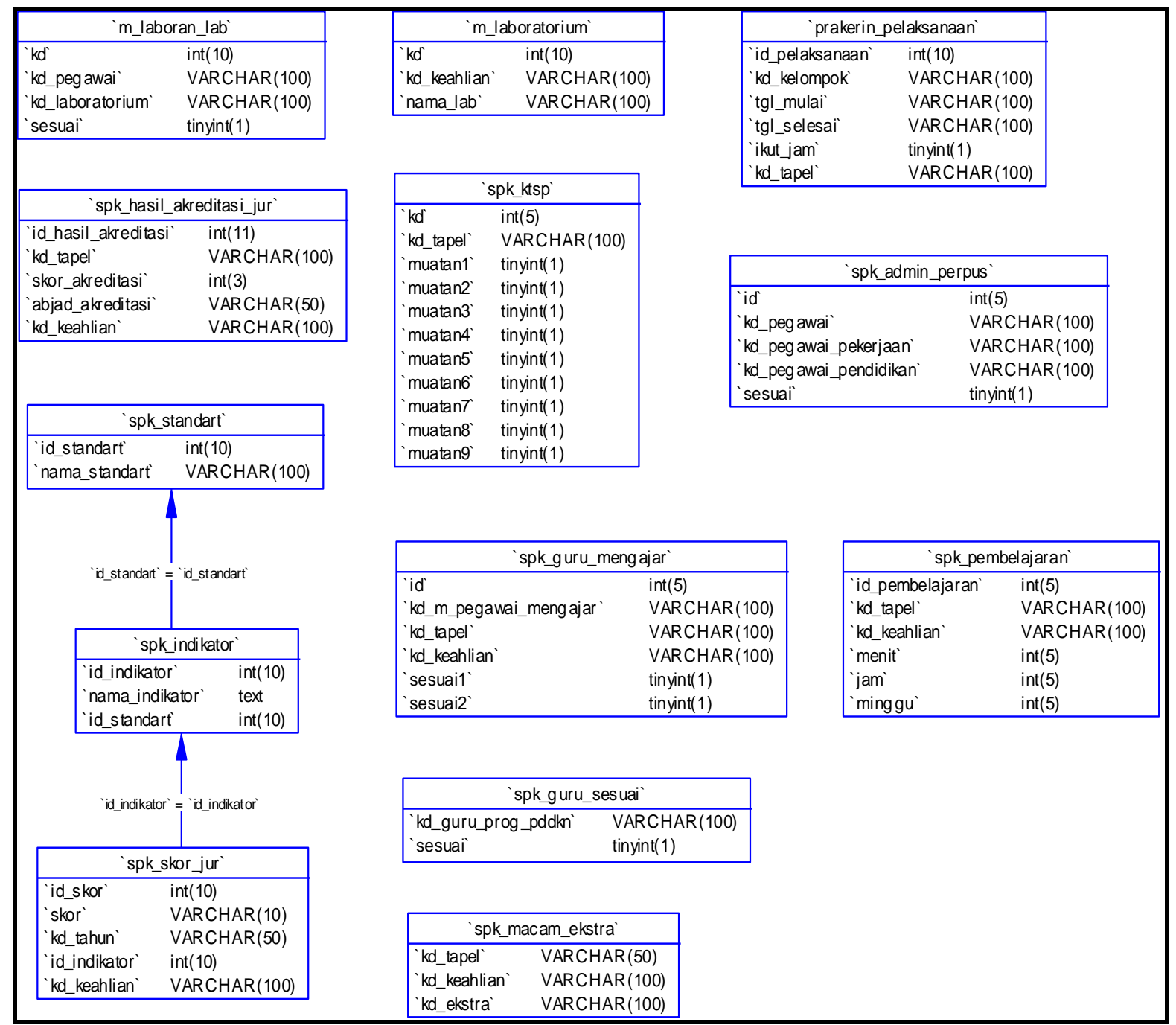

Gambar 3. Entity Relationship Diagram (ERD)

\section{HASIL DAN PEMBAHASAN}

Halaman login adalah halaman pertama yang harus dilalui oleh user sebelum masuk kedalam halaman utama tiap usernya. Halaman utama menunjukkan informasi terkait penilaian. Tampilan informasi akan direpresentasikan dalam bentuk grafik yang dinamis sesuai perubahan data pada sistem yang bertujuan untuk mempermudah user dalam pembacaan data.
Ada empat level dalam sistem ini, yaitu administrator, tata usaha, kepala program keahlian dan kepala sekolah. Level kepala program keahlian dapat melihat informasi sesuai jurusannya. Sedangkan user kepala sekolah dapat melihat informasi seluruh jurusan.

Informasi dalam bentuk grafik ditampilkan dengan tujuan mempermudah dalam membaca informasi. Tampilan halaman utama kepala 
program keahlian dapat dilihat pada Gambar 4 . Ketika kepala program keahlian ingin melihat Indikator apa saja yang dinilai dari penilaia knerja jurusannya maka dapat dilihat pada halaman penilaian seperti pada Gambar 5.

Apabila kepala program keahlian ingin melihat detail dari nilai yang didapat oleh jurusannya maka kepala program keahlian dapat melihat pada halaman detail tiap Indikator yang dinilaidapat dilihat pada Gambar 6.

Untuk halaman utama kepala sekolah, yaitu laporan yang disajikan sudah berdasarkan rata-rata penilaian yang didapat dari seluruh jurusan yang ada pada sekolah tersebut. Selain itu berbeda dengan kepala program keahlian kepala sekolah bisa melihat seluruh laporan penilaian kinerja dari tiap jurusan. Tampilannya pada Gambar 7.

Pada halaman Tata Usaha terdapat lima menu utama yaitu, KTSP, Ekstrakurikuler, Prakerin, Kegiatan Pembelajaran dan Guru Mengajar. Dalam halaman ini Tata Usaha berhak untuk memanajemen seluruh data KTSP, Ekstrakurikuler, Prakerin, Kegiatan Pembelajaran dan Guru Mengajar dalam hal mengupdate data. Setelah data yang diinginkan telah diubah, kemudian klik tombol Simpan. Tampilan halaman manajemen data penilaian pada Gambar 8.

Pada halaman Administrator terdapat dua menu utama yaitu, Standar dan Indikator. Dalam halaman ini Administrator berhak untuk memanajemen seluruh data standar maupun indikator, baik dalam hal mengupdate maupun menghapus data. Gambar 9 merupakan tampilan halaman manajemen data penilaian.

Untuk menghapus data yang ditampilkan, kemudian klik tombol icon Sampah. Ketika ingin mengupdate data klik icon Edit, maka akan muncul halaman update data penelitian seperti gambar 10 . Setelah data yang diinginkan telah diubah, kemudian klik tombol Simpan.

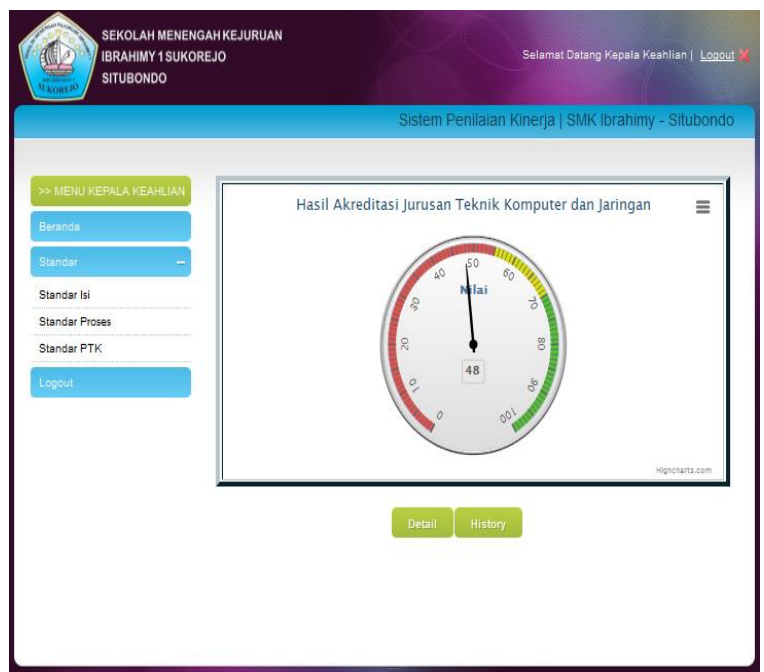

Gambar 4. Halaman Utama Kepala Program Keahlian

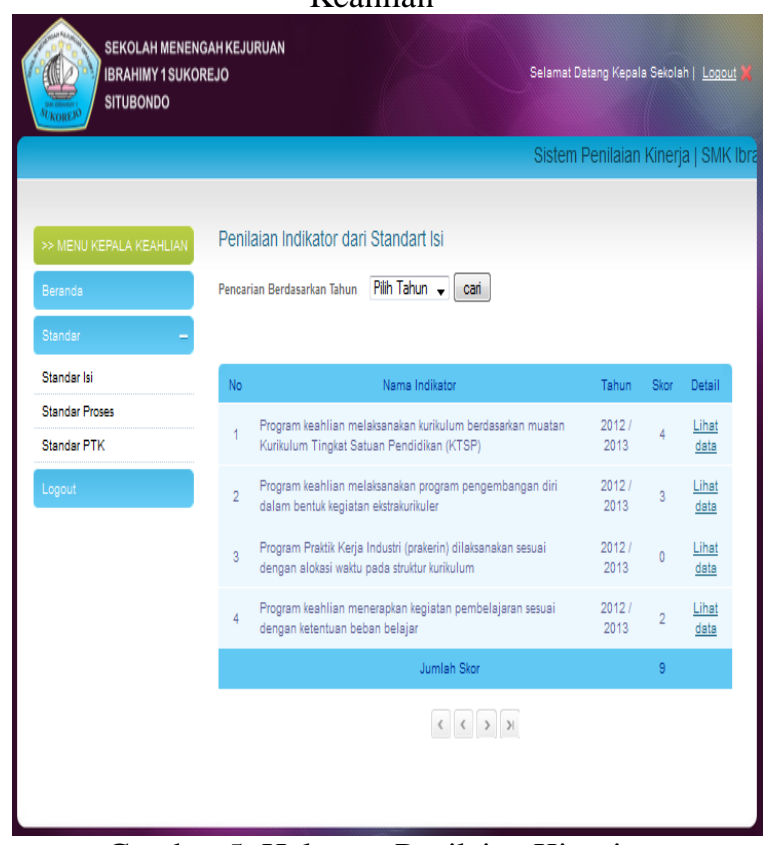

Gambar 5. Halaman Penilaian Kinerja 


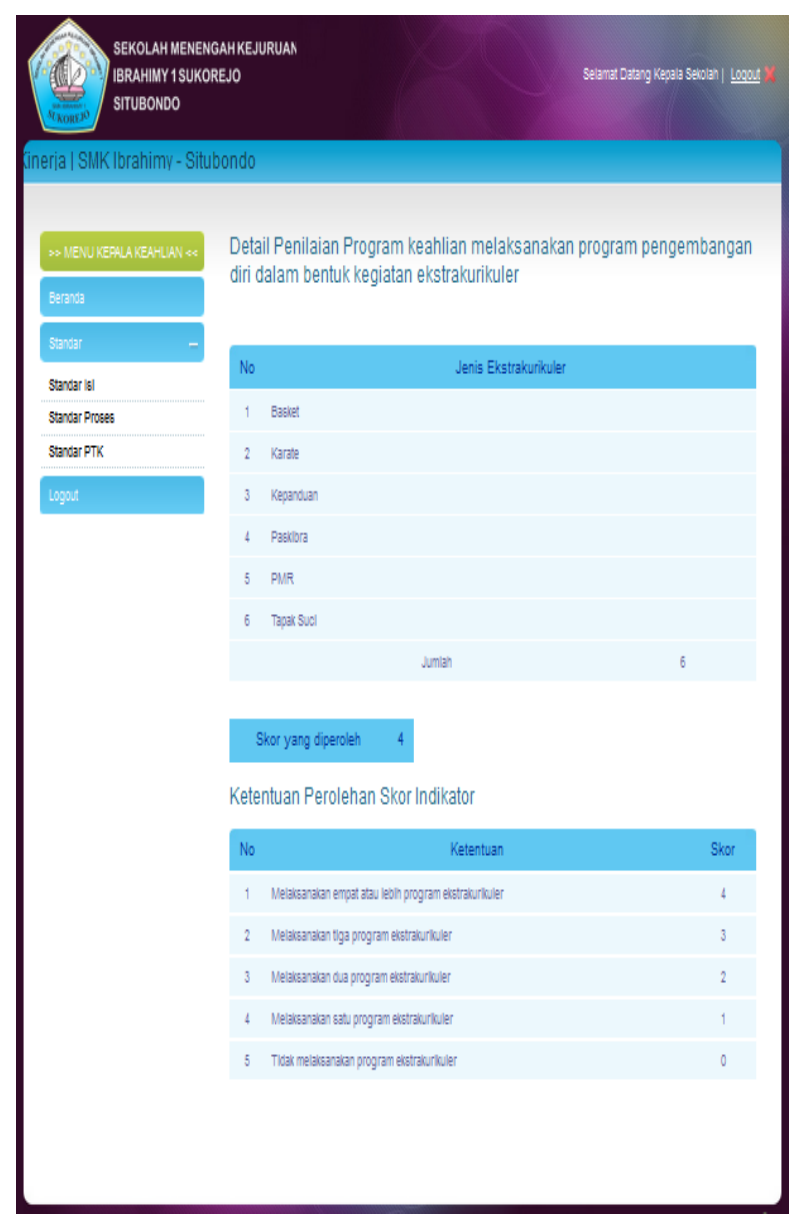

Gambar 6. Detail Nilai

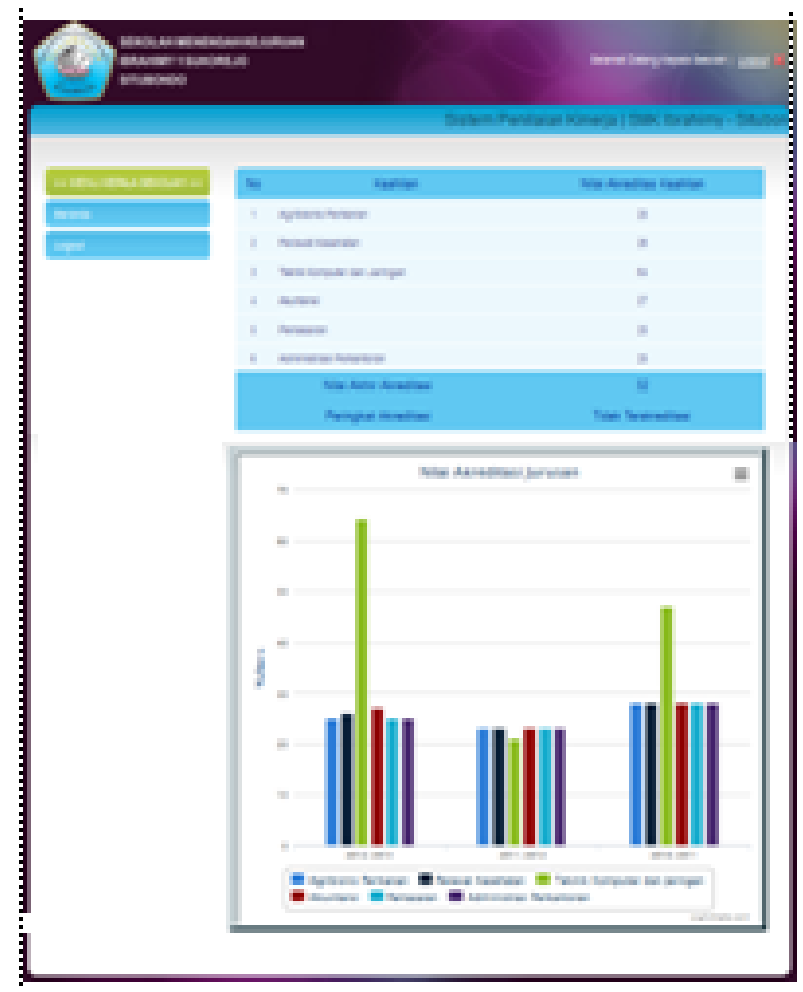

Gambar 7. Halaman Utama Kepala Sekolah

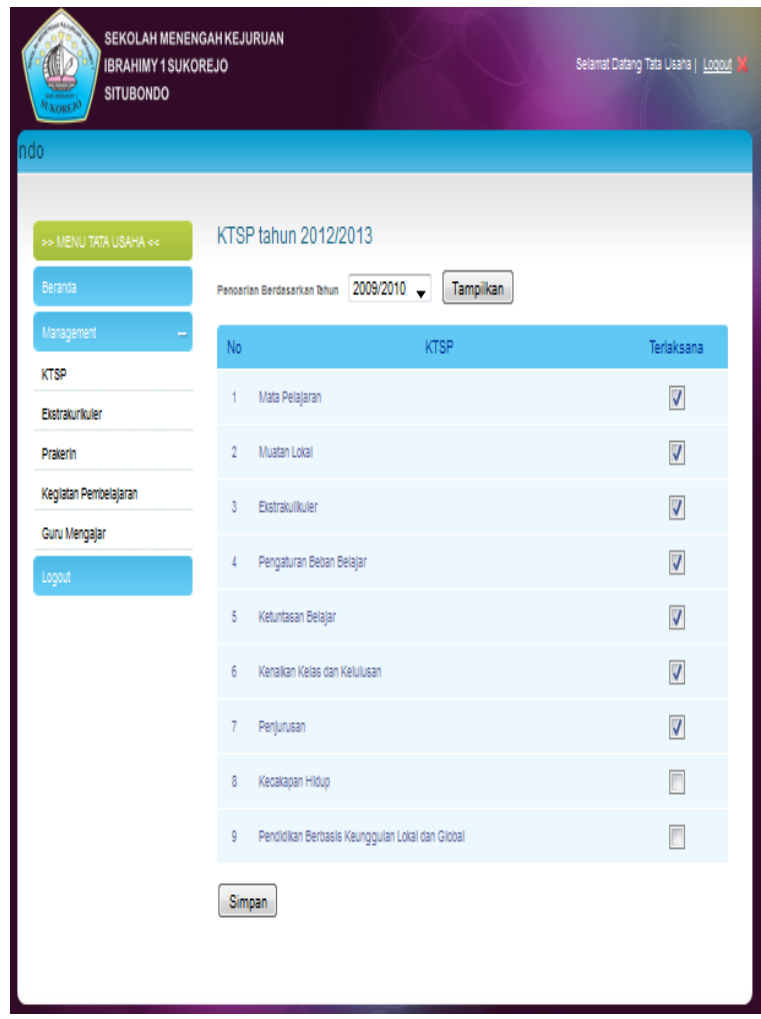

Gambar 8. Halaman Manajemen Data 


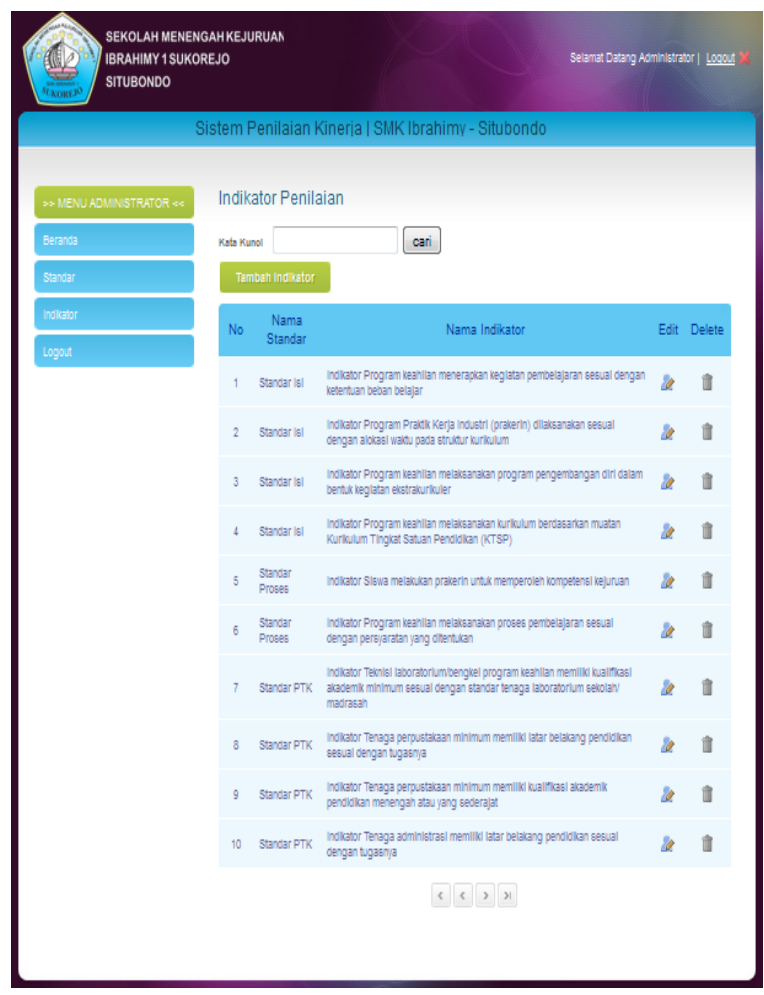

Gambar 9. Halaman Manajemen Penelitian Dosen

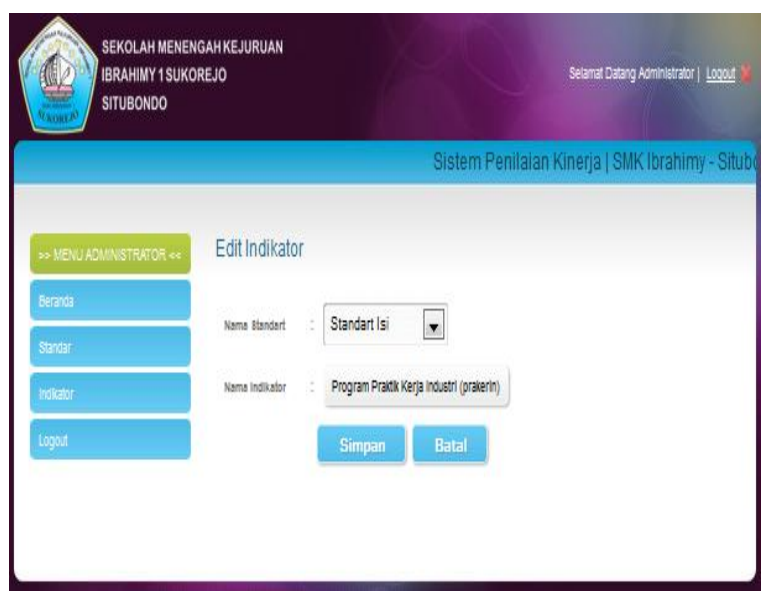

Gambar 1.0 Halaman Update Indikator Penilaian

\section{KESIMPULAN}

Hasil penelitian yang telah dilakukan oleh peneliti, membangun dan menguji Sistem Penilaian Kinerja, diperoleh kesimpulan bahwa:

a. Sistem informasi ini dapat dijadikan sistem yang memonitoring kinerja guru, karyawan maupun kegiatan pembelajaran. b. Sistem informasi ini dapat mengolah data dengan lebih efisien dan bisa diakses dimana saja dan kapan.

\section{PUSTAKA}

[1] Harahap, Yasri Sulaiaman. 2009. Perancanngan sistem penilaian kinerja pegawai berbasis web (studi kasus: SEAMEO BIOTROP, BOGOR)

[2] Rhardja, Untung. 2011. Theory and Aplication of IT Research Metodologi Penelitian Teknologi Informasi. Yogyakarta: C.V ANDI OFFSET

[3] Sulistyawan, Fariz. 2011. Sistem Informasi Penilaian Kinerja Pegawai Menggunakan Metode Graphic Rating Scales 360 Derajat

[4] UU No 20 Tahun 2003 tentang Sistem Pendidikan Nasional

[5] Wardati, Indah Uly. 2008. Decission Suport System Penilaian Kinerja Guru SMK Negeri 1 Pacitan Berdasarkan Standar Kurikulum Tingkat Satuan Pendidikan (KTSP). 